\title{
Personnel in Cataloging Departments
}

The paper following, directs attention to certain considerations in cataloging which have received less attention than have the technical aspects. It was read before the New York Regional Catalog Group, Nov. 24, 1944.

$\mathrm{S}_{\text {ome time ago, in a review article in }}$ S College and Research Libraries, ${ }^{1}$ attention was called to three aspects of personnel management in cataloging departments. These were (I) the alleged lack of discriminatory powers and responsibility on the part of catalogers, (2) the relation of administrative organization to production, and (3) the absence of a recruiting program for cataloging personnel. It is proposed to consider each of these in relation to the general problem of cataloging personnel in libraries, primarily from the standpoint of the subordinate members of the staff.

Five general observations concerning present cataloging personnel may be made. The first is that cataloging is predominantly a feminine occupation. Probably this is truer in cataloging than in some other areas of librarianship. Out of 803 names of persons engaged in cataloging, as given in the Catalogers' and Classifiers' Yearbook for 1937, only twenty-five, or a little more than 3 per cent, were men. This figure does not include male librarians and teachers who did no cataloging. The percentage is probably less at present.

The second observation is that catalogers, 1 Tauber, Maurice F. "Is the Golden Age Really
Over?" College and Research Libraries $3: 183.85$, March 1942. probably more so than other librarians, are inclined to stay fixed in their jobs. That is, there is less mobility from library to library. This is probably truer of the older members of the staff, who are in many instances lacking college and/or library school training, than of recently trained graduates. This has changed considerably during the war period.

The third observation that may be made arises from the war. There is considerable difficulty at present in getting new catalogers. Practically the only way is to attract them by higher salaries from positions in other libraries. It is almost impossible to get male catalogers. At the same time, many libraries are suffering from accumulating arrears. This is a serious situation, since it is likely that libraries will not be in a position to process quickly the foreign materials which may be acquired after the war.

The fourth point to be observed is that salaries for catalogers, considering the experience and training expected of them and the concentrated work they must do, are relatively low. So long as salaries are low, positions in cataloging departments will go begging. This will be especially true at such times as the present, when the practice in most good libraries is to recruit catalogers who have both academic and professional training.

The final observation concerns catalogers as people. Many statements made in the past have been devoted to such matters as efficiency and job analysis, as if these were things dissociated from human beings. 


\section{Ability of Catalogers}

Attention may now be turned to the first of the three points to be discussed-the ability of catalogers. Recently there appeared in the Wilson Library Bulletin two relevant articles, one a rebuttal of the other. The first, "A Philosophical Analysis of Cataloging" ${ }^{2}$ by L. H. Kirkpatrick, contained some caustic criticisms. His remarks were summarized by Marian C. Conroy and M. Lucille Duffy in the second paper, "Cataloger Bites Dog."'3 According to them, Kirkpatrick accused catalogers of bigotry, chronic indecision, donkey-like stupidity, would-be omniscience, and nauseating egoism.

Actually not all of these appellatives were used so explicitly; nevertheless, catalogers lately have been taking considerable verbal pummeling. In a sense, they have become the scapegoat for most of the library's ills. If it is observed here that catalogers are inclined to follow, rather than to question, no slight is intended. In many ways they are no different from other librarians in this respect. Yet there is some evidence that many of them give the impression of being introverted. To support this it may be pointed out that cataloging as a back-stage or off-the-scene process too frequently has been considered by administrators as a type of work that the less competent individuals, and the misfits on the staff, should be given.

This attitude, however, gradually is being changed. The professional and personal qualities of members of the cataloging departments in well-administered libraries are being subjected to the same rigorous examination as those of other members of the staff. The various personnel classification and pay plans appear to recognize this fact.

The real criticisms that have been made of

2 Wilson Library Bulletin $17: 443 \cdot 47$, February 1943 . 3 Wilson Library Bulletin 17:822-25, June 1943 . catalogers may be stated as follows: They are rule-bound and possess little imagination. They have failed to examine their work in the light of the needs of the users. They have neglected to examine the product of cataloging in relation to other library tools, and they are not concerned with cost. They resent criticism of their work and oppose change. Probably all of these charges are true to some extent. Yet catalogers have been among the first to suggest modifications in practices, to meet the wishes of reference and circulation librarians, and to retain an open mind concerning proposals for altering cataloging practices. Catalogers as a group are flexible and will fit into an efficient administrative organization if administrative principles relating to personnel are properly applied. Catalogers, no less than other types of workers, are human beings. They are interested in such things as security, adequacy of pay, fairness, recognition, social approval, occupational adjustment, acceptable working conditions, exercise of initiative and responsibility, and the right to be heard. These are normal demands of all workers, and catalogers have a right to expect that they will be met.

Consider for a moment the question of adequate compensation. Underpaid catalogers are not likely to be interested in such things as attacking back problems, clearing arrears, suggesting new procedures, or developing simple practices. In fact, just the opposite may be true. Like other workers, they are likely to be idle at times and may be tempted now and then to ignore authority, to waste supplies, to handle equipment carelessly, to make errors sufficiently to require constant revision, to do personal work during regular hours of service, to visit and talk about subjects not related to cataloging, and to be tardy and absent. 
Many grievances reflect the resentment and frustration of the individual whose personal progress has been blocked. For example, a worker may be subjected to continuous shift in his surroundings and even in himself. This requires persistent efforts of the administration to assist him in making adjustment. It is often difficult to understand behavior changes, and, because there is no set pattern to these, the head of a department should not be surprised if they appear unexpectedly.

\section{Administrative Organization and Production}

Even though catalogers have been accused of lacking discrimination and a sense of responsibility, this situation usually reflects poor leadership. A well-organized cataloging department in a well-organized library will be as efficient as a well-organized unit in any type of endeavor. If there is a pay system understandable to all, if employees are given a chance to advance, if workers are supervised carefully and are allowed latitude to use judgment and to exercise responsibility, if favorable working conditions are provided, if all staff members are treated on an equitable basis and are rewarded for meritorious service, there is no reason to believe that cataloging production should not reach the highest possible point.

A happy cataloging personnel is generally an efficient personnel. In order to keep a group of workers contented, the head of the department should consistently be concerned about supervision. For example, he should know at all times the progress of the flow of work, as compared with normal requirements. The efficient way to accomplish this is to delegate authority to responsible subordinates. The head also needs to know the quality of the product and the conditions under which it is turned out. As for the former, various factors may be responsible. To control the latter, the supervisor himself should travel through the department often enough, with a list of points to observe, to make adjustments on the basis of factual evidence.

The personal problems of the catalogers always require the attention of the supervisor. The head who waits for overt evidence of emotional disturbances waits too long. He should keep himself close to his group by discussing personal problems with various individuals and make such other contacts as will enable him to anticipate deviations in interest and emotional flareups.

In order that catalogers may not feel as if pressure is being applied to them, the supervisor should always maintain contacts with his superiors, so as to be informed of all probable changes in organization or services. For example, knowledge of an incoming gift will make it possible to protect the department against overloading. Complete information on the part of the supervisor should aid him in preparing the catalogers to meet the plans of the administration. The staff should know what is contemplated but, in order to prevent undue uneasiness, not before developments are fairly well along.

\section{Code of Discipline}

A cataloging group, just as an industrial group, evolves as a rule its own code of discipline. Restriction of output is an example of this. It is not unusual that if a cataloger produces an extraordinary amount of work she is looked on with suspicion by other members of the department. She is frequently accused of inaccuracy. Established standards of performance should eliminate this. Similarly, the laggard is regarded with suspicion and dislike. The administrator can maintain morale by removing such a person or by changing his work.

A good leader can exercise a great deal 
of influence over the kind of self-discipline a group develops. If the attitude is against the interest of the library, the librarian or the head of the department must share the responsibility for neglect or failure to direct it properly. The head, likewise, may have other important effects upon the group. If he is fair to the workers, while protecting the interest of the library, he will find that his subordinates respond. If he places the interest of the library above those of the workers, at the latter's expense, he may discover that the staff members are not only uncooperative but antagonistic. The wise administrator also will seek out in the cataloging staff the individuals who can participate in projects and committee work. Incidentally this will give them a library outlook rather than a departmental one.

An efficient cataloging department is usually characterized by the active participation of all staff members. One of the best ways of developing this is to solicit suggestions. Suggestions so derived serve two purposes. They stimulate the worker and they serve as a basis for singling out for promotion the more competent individuals in the department. Moreover, a wellregulated suggestion plan should improve methods of work and reduce the cost of cataloging. There, of course, should be a wise distribution of praise and reprimands when occasions warrant them.

There are other ways of applying administrative principles to cataloging production. The establishment of quotas and efficiency ratings have been frowned upon, but this practice should not be discarded without due consideration of the possibilities involved. The presence of adequate mechanical equipment, staff manuals, codes for preparing copy, reference works, and sufficient clerical assistance-these undeniably aid in providing a strong underpinning for efficient organization.

Recently Amy Wood Nyholm remarked that she has "noticed no library worker more subject to wearing, demanding, and exacting pressures than is the head cataloger of a large and important library who fully understands and accepts his responsibility." ${ }_{4} \mathrm{He}$ mist turn to account the malingerers, the sporadic workers, and the slavish rule-followers who may have got into his staff group. He must reconcile the administrator who talks only in terms of costs. He must guard against the reference and circulation librarians who consider the catalog as the fountainhead of all answers.

\section{Solution}

What is the solution to all this? How can the catalog administrator and his staff do the things that are expected or demanded of the cataloging department? First of all, there must be a definite program or policy for cataloging, based on the needs of the users of the individual library. This requires that the functional aspects of cataloging be thoroughly investigated. Herman H. Henkle and his staff at the Library of Congress are studying this problem, and it is likely that their findings will be useful to other catalogers and administrators. ${ }^{5}$

Second, a clear differentiation of the professional and the clerical aspects of cataloging is needed. If there can be careful analyses of jobs and distribution of duties, the professional staff members need not be given the time-consuming routine tasks that can be handled satisfactorily by clerical workers.

Third, this differentiation should make cataloging a more attractive occupation than it is now. Then there could be a recruiting program for "able and intelligent young men and women of sound judgment who have the personal traits of keen

\footnotetext{
Library Quarterly 14:360, October 1944 .

5 Henkle, Herman H. "Library of Congress Con. ferences on Cataloging, October I8-November 19, 1943." (Manuscript).
}

(Continued on page 248) 
Wittenberg College, Springfield, Ohio

Excelsior Society, 1845

Philosophian Society, 1847

Yale University, New Haven, Conn.

Brothers' \& Linonian Society

Brothers in Unity, 1768

Calliopean Society

Linonian Society, 1753

Moral Society

Phoenix Society

* Manuscript copy.
I850, 1877

1876 (?)

$1808,1811,1814,1818,1822,1825,1873,1880$, suppl. to $\mathrm{r} 873$

$1781 * 1829,1832,1835,1838,1841,1846, \quad 1851$ I819, 1824, I826, I828, I 829 , suppl., I831, 1837, I $84 \mathrm{I}, \mathrm{I} 846$

1770*, 1780*, 1790*, 1800*, 1829, 1831, 1834, $1836,1837,1840,1841,1846$, r 860

$1814,1818,1822,1825$

$1806(?)$

\section{Sources of Reports and Statistics}

American Almanac and Repository of Useful Knowl. edge for 1830-40. Boston, 1829-39. v. I-II.

American Annals of Education and Instruction, 1834, 1835, 1836. Boston, 1834-36, v. 4-6.

American Quarterly Register and Journal of the American Education Society, 1828-31. Andover, etc., Mass., 1829-31. v. I-3.

Cutter, Charles A. "List of Printed Catalogues of Public Libraries in the United States." (In U.S. Office of Education. Public Libraries in the United States of America. Washington, Government Printing Office, 1876, p. 577-622.)

Jewett, Charles Coffin. Notices of Public Libraries in the United States of America. Printed by order of Congress, as an appendix to the fourth annual report of the Board of Regents of the Smithsonian Institution. Washington, Printed for the House of Representatives, I85 I. 207P.

Rhees, William Jones. Manual of Public Libraries, Rhees, William Jones. Manual of Public Libraries,
Institutions, and Societies, in the United States, and
British Provinces of North America. Philadelphia, Lippincott, 1859. 28, 687p.

Seeley, I C. Manual of College Literary Societies with Statistical Tables. Kalamazoo, $187 \mathrm{r}$. $145 \mathrm{p}$.

U.S. Office of Education. Public Libraries in the United States of America; Their History, Condition and Management. Special report. Department of Interior, Bureau of Education. . . Washington, Government Printing Office, 1876. 2v, in $\mathrm{I}$.

U.S Office of Education "Public Society and Schooi Libraries in the United States; with Library Statistics and Legislation of the Various States." 1896, 1900, etc. (In Report of the Commissioner of Education, I895-96, I899-1900, etc. Washington, Government Printing Office, 1897, 1901, etc.)

U.S Office of Education. "Statistics of Public Libraries in the United States Nimbering 300 Volumes and Upwards for 1884-85." (In Report of the Commissioner of Education, 1884-85. Washington, Government Printing Office, 1886 . ccxxix-ccxxx, 691-782p.)

\section{Personnel in Cataloging Departments}

\section{(Continued from page 227)}

alertness, self-confidence, perception, flexibility, and balance."'6 According to Mrs. Nyholm, who listed the qualities above, these people could withstand aggressive and demanding pressures and make decisions based on "soundness" and "survival value." Finally, a good deal more attention should be given by administrators to catalogers as people. This seems so obvious that one hesitates to repeat it, yet the epidemic of criticism suggests that administrators, in their great desire to emerge from a bad situation, have not always used the proper approach.

- Op. cit. 